\title{
Delaney's revenge: Court rejects US approach to assessing cancer risks in processed foods
}

Washington. US risk assessment officials for years have been quietly devising novel interpretations to get around restrictive and, many researchers argue, scientifically outdated - laws on the use of potential carcinogens in food and water. Last week, however, that regulatory house of cards collapsed.

A federal court in California ruled on 8 July that the US Environmental Protection Agency (EPA) must abide by the letter of the so-called 'Delaney clause' of the 1958 Food, Drug and Cosmetic Act, which prohibits processed foods from containing any chemical found to cause cancer in animals or humans at any concentration. It rejected EPA's argument that it was following the intent of the law to protect consumers from unreasonable risk. As well as reversing decades of regulatory policy and potentially making illegal many of the pesticides now used by US farmers, the ruling strengthens efforts in Congress to overturn the law and to adopt instead a standard that reflects current knowledge of the complex mechanisms of carcinogenicity (see Nature 353, 289; 1991).

Improved detection methods have shown that more agricultural chemicals may be present in food after processing than was thought in 1958 to be the case. And more sophisticated testing has shown that some of those chemicals may not be entirely noncarcinogenic. Some, such as saccharine, cause cancer at high doses in mice or rats, but their danger to humans is less well understood. Others, like benomyl, a fungicide used on raisin grapes and tomatoes intended for processing, and phosmet, an insecticide detected in cottonseed oil, appear to pose definite but slight human risks - of the order of one new cancer in between 10 million and 100 billion people.

EPA studies have shown that at least 67 of about 300 pesticides now used in US agriculture cause cancer in one or more

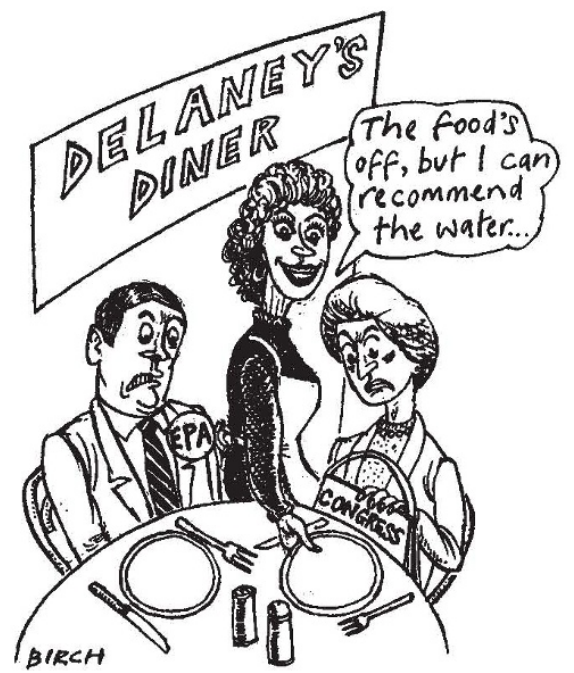

species of laboratory animal. About 35 of those chemicals are used in processed foods and would be banned under a strict interpretation of the law.

In 1989, realizing that strict adherence to the Delaney clause would make it impossible to approve many of the pesticides now in common use, the EPA adopted a 'negligible risk' policy that permits the use of potentially carcinogenic chemicals if their risk is less than one additional case of cancer per million people exposed. But last year, the Natural Resources Defense Council challenged that interpretation in court.

"The EPA in effect asks us to approve what it deems to be a more enlightened system than that which Congress established", the appellate judge, Mary Schroeder, wrote in a unanimous opinion. "Revising the existing statutory scheme, however, is neither our function nor the function of the EPA. If there is to be a change, it is for Congress to direct."

EPA officials expected to lose the case. Although the agency could appeal against the decision, it would prefer to see Congress change the law.

Four bills before Congress would do just that. But although all the bills were introduced last year, none has moved ahead because legislators have been awaiting both last week's ruling and a report by the National Academy of Sciences due out later this month.

Now that the California court has passed the baton to Congress, legislators are expected to take up the issue quickly. Twin bills proposed by Henry Waxman (Democrat, California) in the House of Representatives and Ted Kennedy (Democrat, Massachusetts) in the Senate are likely to move the fastest. Those bills, which include children in setting a threshold for any chemical, are more restrictive than some of the other proposals. But in the wake of last week's court decision, both EPA and industry are eager to escape from the Delaney clause, and the Waxman-Kennedy legislation is helped by support from several environmental groups.

Christopher Anderson

\section{One policy for all?}

Although the US government would most like to resolve the dilemma of zero-risk posed by the Delaney clause, regulating risks outside agricultural chemicals is also the subject of sharp debate. An interagency committee under the White House Office of Science and Technology Policy has been working for the past year on a set of broad risk-assessment guidelines for all federal agencies, including the Food and Drug Administration (FDA), the Occupational Safety and Health Administration and the Environmental Protection Agency (EPA). The guidelines, which are expected to be issued in the next month or so as a presidential executive order, would create a central review panel for risk decision, perhaps under the direction of the White House.

Industry and environmental groups want to help shape the guidelines, which will be the first major change to US riskassessment policy in three years. One proposed draft, offered to the White House by Federal Focus, an influential industry-funded group, would encourage regulators to use a variety of riskassessment methodologies rather than just the so-called linear modelling now favoured by the EPA.

In linear modelling, regulators assume that a chemical that causes cancer in large doses will cause proportionally fewer (but not zero) cancers at small doses. But some chemicals, such as dioxin, appear to have a 'threshold' concentration below which they may not be carcinogenic. Linear modelling may exaggerate the danger of nonmutagenic carcinogens.

The Federal Focus guidelines also encourage regulators to give equal weight to negative results when making risk decisions. Although many researchers agree that negative results are important, there is concern about lending credibility to flawed studies that may obscure signs of possible carcinogenicity.

Environmental groups are concerned that moving risk decisions away from the science-based agencies such as EPA and FDA to a central group controlled directly by the White House may allow politics to take precedence over science. Ironically, that is just what the Bush administration said was wrong with the Delaney clause when it moved to a new standard in 1989. As proof, environmentalists point to the growing use by the administration of such nonscientific calculations as regulatorycost-per-life-saved in calculating acceptable risk. 